ZOOLOGIA 30 (1): 24-34, February, 2013

http://dx.doi.org/10.1590/S1984-46702013000100003

\title{
Seasonal habitat selection of the red deer (Cervus elaphus alxaicus) in the Helan Mountains, China
}

\author{
Mingming Zhang ${ }^{1}$, Zhensheng Liu ${ }^{1,2} \&$ Liwei Teng ${ }^{1,2,3}$
}

\author{
${ }^{1}$ College of Wildlife Resources, Northeast Forestry University, No.26 Hexing Road, Xiangfang District, Harbin 150040, P.R. \\ China. \\ ${ }^{2}$ Key Laboratory of Conservation Biology, State Forestry Administration, No.26 Hexing Road, Xiangfang District, Harbin \\ 150040, P.R. China. \\ ${ }^{3}$ Corresponding author. E-mail: tenglw@gmail.com
}

\begin{abstract}
We studied the seasonal habitat selection of the red deer, Cervus elaphus alxaicus Bobrinskii \& Flerov, 1935, in the Helan Mountains, China, from December 2007 to December 2008. Habitat selection varied widely by season. Seasonal movements between high and low elevations were attributed to changes in forage availability, alpine topography, the arid climate of the Helan Mountains, and potential competition with blue sheep, Pseudois nayaur (Hodgson, 1833). The use of vegetation types varied seasonally according to food availability and ambient temperature. Red deer used montane coniferous forest and alpine shrub and meadow zones distributed above 2,000 $\mathrm{m}$ and 3,000 $\mathrm{m}$ in summer, alpine shrub and meadows above 3,000 $\mathrm{m}$ in autumn, being restricted to lower elevation habitats in spring and winter. The winter habitat of C. elaphus alxaicus was dominated by Ulmus glaucescens Franch. and Juglans regia Linnaeus, deciduous trees, and differed from the habitats selected by other subspecies of red deer. Cervus elaphus alxaicus preferred habitats with abundant vegetation coverage to open habitats in winter, but the reverse pattern was observed in summer and autumn. Red deer preferred gentle slopes $\left(<10^{\circ}\right)$ but the use of slope gradient categories varied seasonally. Red deer avoidance of human disturbance in the Helan Mountains varied significantly by season. Information on red deer habitat selection can help understand the factors affecting seasonal movements and also support decision making in the management and conservation of red deer and their habitats.
\end{abstract}

KEY WORDS. Habitat use; migration; seasonal movement; ungulates.

The red deer, Cervus elaphus alxaicus Bobrinskii \& Flerov, 1935 is an endemic subspecies in China, distributed in the central region of the Helan Mountains, which range from the border between Alxa League of the Inner Mongolia Autonomous Region to the Ningxia Hui Autonomous Region in west-central China. The Helan Mountains support the only known population of this subspecies (WANG et al. 1999). Its population is small and is isolated from other subspecies of red deer (ZHANG et al. 1999). Historically, the survival of C. e. alxaicus has been threatened by the deterioration of habitats on the Alxa Plateau, and its reduced population has since been isolated in the relatively poor ecological environment of the Helan Mountains for a long period. Population estimates for C. e. alxaicus in the Helan Mountains ranged from 850 to 1,060 in 1983, increasing to $1,705 \pm 523$ in 2005, after the creation of the Ningxia Helan Mountain Nature Reserve in 1982 (ZhANG et al. 2006). While $C$. e. alxaicus is a threatened subspecies, C. elaphus is categorized as a species of Least Concern in the World Conservation Union's Red List of Threatened Animals (Lovari et al. 2008).
Habitat selection by animals is considered as an optimization process that involves factors such as food supply, conspecific population density, body size, competitors, predators, and landforms (MORRISON et al. 1998). Information on which resources are preferred or avoided by organisms improves our understanding of how they meet their requirements for survival and reproduction (MANLY et al. 2002). The distribution and availability of trophic resources are important factors that affect habitat selection. In most temperate habitats, food is scarce during the winter months and abundant in spring and early summer (MoEN 1976, Schмiтz 1991). This forces animals in temperate regions to adapt to seasonal changes in food supply. Ungulates that inhabit temperate and boreal regions often exhibit cyclical seasonal movements between summer and winter ranges in response to environment factors (e.g., snow conditions, food availability), social constraints and predation risk (FryXell \& SinCLAIR 1988, PÉpIN et al. 2008). Regular, round-trip movements between seasonal home ranges (White \& Garrott 1990) have evolved to enable animals to avoid undesirable conditions at a particular 
time of the year (VAUGHAN et al. 2000). Generally, seasonal movement patterns of ungulates include short-distance movements, dispersal, and migration (Grovenburg et al. 2009). Seasonal migration of cervids involves dispersal to areas of lower elevation, particularly in winter, when the environment is less hospitable at higher elevations (Albon \& Langvatn 1992, Igota et al. 2004, Pépin et al. 2008). Mixed strategies of migration have, however, been found among cervids that inhabit temperate and boreal mountainous regions (IGOTA et al. 2004, BRINKMAN et al. 2005, Grovenburg et al. 2009).

Despite numerous studies of other subspecies of red deer, little is known about the seasonal habitat use or movement patterns of C. e. alxaicus during different seasons. The objective of this study was to: 1) compare habitats used by $C$. $e$. alxaicus during different seasons to document differences in habitat selection; and 2) examine environmental variables that affect the seasonal movement of C. e. alxaicus.

\section{MATERIAL AND METHODS}

This study was conducted over four seasons from December 2007 to December 2008 in the Helan Mountain region, which is located between the eastern Yinchuan plain in Ningxia Hui Autonomous Region and the western Alxa Plateau in Inner Mongolia Autonomous Region $\left(105^{\circ} 44^{\prime}-106^{\circ} 42^{\prime} \mathrm{E}, 38^{\circ} 21^{\prime}\right.$ $39^{\circ} 22^{\prime} \mathrm{N}$ ) (Fig. 1). The Helan Mountain region, located in northwestern China, is on the transitional zone between steppe and desert regions of central Asia (TAKHTAJAN 1986). It generally lies at 2,000-3,000 masl, with a maximum elevation of 3,556 masl. It covers an area of $2,740 \mathrm{~km}^{2}$ [including Ningxia Helan Mountain National Nature Reserve $\left(2,063 \mathrm{~km}^{2}\right)$ and Inner Mongolia Helan Mountain National Nature Reserve (677 km², Fig. 1)], with a north-south length of about $250 \mathrm{~km}$ and an east-west width of about 20-40 km (Z.S. Liu unpublished data).

The region has a typical continental climate, characterized by cool and dry conditions, with annual mean temperature of $-0.9^{\circ} \mathrm{C}$ and mean annual rainfall of $420 \mathrm{~mm}$. The local climate is influenced by the topography of the Helan Mountain, the low temperature center of the northern Ningxia. The maximum monthly mean temperature is $11.9^{\circ} \mathrm{C}$, in July, and the minimum is $-14.2^{\circ} \mathrm{C}$, in January, $8.8 \sim 9.8^{\circ} \mathrm{C}$ lower than in Yinchuan, the capital city of Ningxia Hui Autonomous Region. Precipitation varies seasonally, with $62 \%$ falling as rain in summer. There is little precipitation in winter, about $10.1 \%$ of the annual total. Snow cover is limited in the Helan Mountains (GeNG \& YANG 1990). The vegetation distribution is strongly influenced by moisture conditions. The elevation differential between the Helan Mountains and the plains to the south and east is about $2100 \mathrm{~m}$, which creates an elavational climatic gradient that results in the formation of four elevational vegetation zones. The mountain steppe zone (MS) occurs at 1,400-1,600 masl and covers an area of $1,241 \mathrm{~km}^{2}$ dominated by Stipa breviflora Griseb., Ajania fruticulosa (Ledeb.) Poljak,

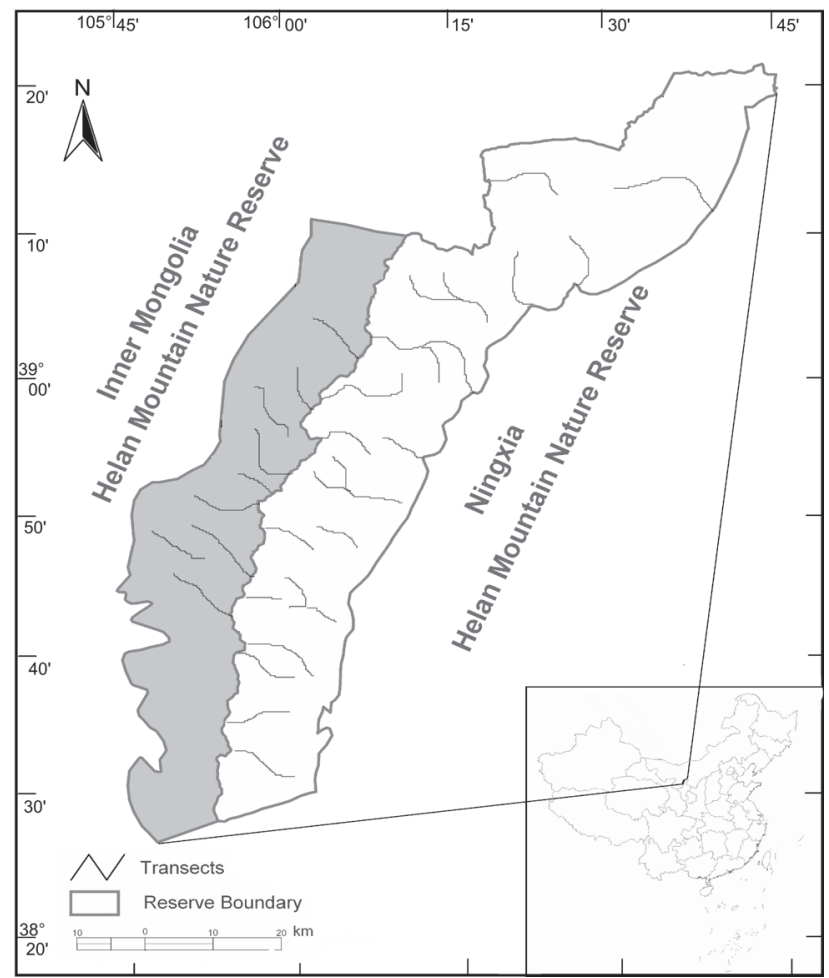

Figure 1. Location and distribution of the study area and transects in the Helan Mountain region, China. Grey shading represents Helan Mountain Nature Reserve in Inner Mongolia Autonomous Region, while the unshaded area represents the reserve in Ningxia Hui Autonomous Region.

Ptilagrostis pelliotii (Danguy) Grubov.), Oxytropis aciphylla Ledeb.), Convolvulus gortschakovii Schrenk ex Fisch. \& C.A. Mey., and Salsola laricifolia Turcz. ex Litv. The open mountain forest and steppe zone (MOFS) (1,600-2,000 masl, 1,155 km²) is dominated by Ulmus glaucescens Franch., Prunus mongolica Maxim., Stipa grandis P.A. Smirn., and S. bungeana Trin. The mountain coniferous forest zone (MCF) $\left(1,900-3,000\right.$ masl, $\left.319 \mathrm{~km}^{2}\right)$ is dominated by Picea crassifolia Kom., Pinus tabulaeformis Carrière, Juniperus rigida Siebold \& Zucc., and Potentilla parvifolia Fisch. ex Lehm. The alpine shrub and meadow zone (ABM) (3,0003,556 masl, $23 \mathrm{~km}^{2}$ ) is dominated by Salix cupularis var. lasilogyne Rehd., Caragana jubata (Pall.) Poir., Kobresia spp., Polygonum viviparum Linnaeus and Arenaria spp. (JIANG et al. 2000, Di 1986). Mammals found in the area include insectivores: Daurian hedgehog, Mesechinus dauuricus (Sundeyall, 1842); carnivores: red fox, Vulpes vulpes (Linnaeus, 1758); artiodactyls: blue sheep, alpine musk deer: Moschus chrysogaster (Hodgson, 1839); lagomorphs: Daurian pika, Ochotona dauurica (Pallas, 1776); and chiropterans and rodents. Blue sheep and C. e. alxaicus are the two dominant ungulate species in the Helan Mountain region (Liu 2009). 
From December 2007 to December 2008, we carried out four surveys, one per season, to determine the distribution of C. e. alxaicus throughout the Helan Mountain area. Each seasonal survey sampled 32 line transects established along the valleys and each survey took about one month to sample all topographic types. Differences in topographic relief prevented walking along the transects at the same velocity and length, therefore, transects ranged in length from 4.5 to $8.5 \mathrm{~km}$, for a total of $350 \mathrm{~km}$ traversing the whole study area and covering all four elevational vegetation zones. The distance between any two transects was at least $2 \mathrm{~km}$, to ensure the independence of each transect.

Because of the rarity of C. e. alxaicus in the area and their high sensitivity to anthropogenic disturbance (JEPPESEN 1987), we documented habitat use mainly by recording fresh signs, such as evidence of bedding or the presence of feces. We also observed deer in order to record their activities. It was easy to differentiate the signs left by C. e. alxaicus from those of other ungulates (e.g., P. nayaur, M. chrysogaster) in the Helan Mountains, because C. e. alxaicus is larger than $P$. nayaur and $M$. chrysogaster, and the size and shape of their feces are different (CHANG \& XIAO 1988). To ensure the accu- racy of data, we recorded fresh feces only (3-5 days old as estimated by the color and water content). When deer were observed during line transect surveys, we first used telescopes to observe their feeding or bedding behavior, without disturbing the animals. After deer had departed the area, we carried out detailed sampling.

We recorded terrestrial coordinates according to a Global Positioning System (GPS) after a feeding or bedding habitat was identified. We then established a plot with five sample quadrants (Fig. 2) to collect data of 18 topographic and biological variables (Table I) using the methods described by Liu et al. (2002). The distance between any two plots was at least 500 $\mathrm{m}$ to ensure the independence of each plot (Fig. 2).

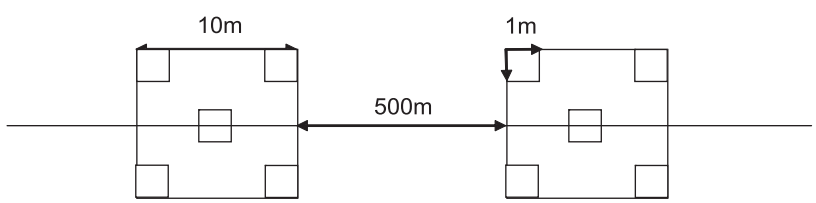

Figure 2. Diagramatic presentation of the survey transects, plots and sample quadrats used in this study.

Table I. Variables collected in feeding and bedding habitat plots used by Cervus elaphus alxaicus in the Helan Mountain region, China.

\begin{tabular}{|c|c|c|}
\hline Variables & Categorization and Criterion & Abbreviation \\
\hline Altitude (m) & The altitude of the plot accorded to GPS & $\mathrm{AL}$ \\
\hline Vegetation types & $\begin{array}{l}\text { Mountain steppe zone (MS); Mountain open forest and steppe zone (MOFS); Mountain coniferous } \\
\text { forest zone (MCF); Alpine bush and meadow zone (ABM) }\end{array}$ & VT \\
\hline Topography & $\begin{array}{l}\text { Categorized by the slope and fault of a hillside, divided into } 5 \text { levels: Smooth undulating slope; } \\
\text { Moderately broken slope; Distinctly broken slope; Scree/landslide; Cliff }\end{array}$ & TO \\
\hline Dominant tree & $\begin{array}{l}\text { The tree covers } 70 \% \text { of the density in the } 10 \times 10 \mathrm{~m} \text { plot. It usually was Ulmus glaucescens, Ziziphus } \\
\text { jujube, Salix spp., Juniperus rigida, Pinus tabulaeformis, Picea crassifolia Mixture or Open land with } \\
\text { no tree }\end{array}$ & DT \\
\hline Tree density (trees/100 $\mathrm{m}^{2}$ ) & The total number of trees in the $10 \times 10 \mathrm{~m}$ plot & TD \\
\hline Tree height $(\mathrm{m})$ & The mean height of trees in the $10 \times 10 \mathrm{~m}$ plot & $\mathrm{TH}$ \\
\hline Distance to the nearest tree $(\mathrm{m})$ & Distance from the center of the $10 \times 10 \mathrm{~m}$ plot to the nearest tree & DtT \\
\hline Shrub density (trees/100 $\mathrm{m}^{2}$ ) & The number of shrubs in the $10 \times 10 \mathrm{~m}$ plot & SD \\
\hline Shrub height $(\mathrm{m})$ & The mean height of shrubs in the $10 \times 10 \mathrm{~m}$ plot & $\mathrm{SH}$ \\
\hline Distance to the nearest shrub (m) & Distance from the center of the $10 \times 10 \mathrm{~m}$ plot to the nearest shrub & DtS \\
\hline Slope gradient $\left({ }^{\circ}\right)$ & Slope gradient of the hillside where the spot located measured with military compass & SG \\
\hline Slope location & $\begin{array}{l}\text { A visual assessment of the site location relative to the macroslope which is usually from valley bottom } \\
\text { to ridge top, classed as: lower slope (includes valley bottom and flat), middle slope and upper slope } \\
\text { (includes ridge top) }\end{array}$ & SL \\
\hline Slope aspect & $\begin{array}{l}\text { Aspect was surveyed to eight compass points, translated as } 0^{\circ}, 45^{\circ}, 90^{\circ}, 135^{\circ}, 180^{\circ}, 225^{\circ}, 270^{\circ} \text { and } 315^{\circ} \\
\text { from North, as } 0^{\circ} \text { is equivalent to } 360^{\circ} \text {. And the slope aspect was grouped into } 3 \text { main directions: } \\
\text { sunny slope }\left(135^{\circ} \sim 225^{\circ}\right) \text {, partial shade slope }\left(45^{\circ} \sim 135^{\circ} \text { and } 225^{\circ} \sim 315^{\circ}\right) \text { or shady slope }\left(315^{\circ} \sim 45^{\circ}\right)\end{array}$ & SA \\
\hline Distance to water resource $(\mathrm{m})$ & The distance from the spot to the nearest water resource & DtW \\
\hline Distance to human disturbance $(\mathrm{m})$ & $\begin{array}{l}\text { The distance from the spot to the nearest place of human activity such as highway, road and shelter } \\
\text { forest station, etc }\end{array}$ & DtH \\
\hline Distance to bare rock $(\mathrm{m})$ & The distance from the spot to the nearest bare rock & DtR \\
\hline Hiding cover $(\%)$ & $\begin{array}{l}\text { The coverage of the hiding conditions. Percent hiding cover was determined by visually estimating the } \\
\text { percent of a deer or a substitute (a } 1 \mathrm{~m} \text { stick) obscured at } 30 \mathrm{~m} \text { in the four cardinal directions (KUNKEL } \\
\text { \& PLETSCHER 2001) }\end{array}$ & $\mathrm{HiC}$ \\
\hline
\end{tabular}


Generally, research on resource selection requires a comparison of the habitats used by C. e. alxaicus (observed plots) with those that are available (expected plots, assuming no differential selection by deer). To provide comparison plots for the analysis of habitat selection, 617 randomly located plots were surveyed. The random plots were established along the survey transects, in areas with no obvious evidence of C. e. alxaicus use. The distance between random plots and occupied plots or any two random plots was at least $500 \mathrm{~m}$ to reduce the possibility of overlap between used and unused plots. Comparison plots were surveyed in each vegetation zone according to the proportion of used plots in each zone. Data were recorded for comparison plots using the same methods used in the occupied plots.

Data were analyzed to quantify habitat selection by C.e. alxaicus by season. To assess seasonal differences between the 18 factors recorded at used plots and comparison plots, we used a chi-square goodness-of-fit test within classified categories for each variable (Marcum \& LoftsgaARden 1980). P-values less than 0.05 were considered statistically significant. Bonferroni confidence intervals were calculated by the following formula to identify variables that indicate preference or avoidance, following the method developed by Neu et al. (1974) and ByERs et al. (1984). $\left(p_{i}-r_{i}\right) \pm Z_{1-\alpha / 2 k} \times \sqrt{p_{i}\left(1-p_{i}\right) / n_{i}+r_{i}\left(1-r_{i}\right) / m_{i}}$; where, $n_{i}$ is the number of comparison plots in category $i$, and $p_{i}$ is the proportion of the comparison plots that fall in category $i ; m_{i}$ is the total number of plots used by C. e. alxaicus, $r_{i}$ is the proportion of plots used by C. e. alxaicus in category $i ; Z_{1-a / 2 k}$ is the upper standard normal table value corresponding to a probability tail area of $1-a / 2 k$; $a$ is the level of significance; and $k$ is the number of categories tested. The confidence intervals indicated that C.e. alxaicus showed avoidance (marked "-") of category $i$ when $\left(p_{i}-r_{i}\right)-Z_{1 \alpha / 2 k} \times \sqrt{p_{i}\left(1-p_{i}\right) / n_{i}+r_{i}\left(1-r_{i}\right) / m_{i}}>0$; whereas C.e. alxaicus showed preference (marked “+”) for category $i$ when $\left(p_{i}-r_{i}\right)+Z_{1 \alpha / 2 k} \times \sqrt{p_{i}\left(1-p_{i}\right) / n_{i}+r_{i}\left(1-r_{i}\right) / m_{i}}<0$; and C. e. alxaicus showed no obvious selection (marked " $=$ ") for category $i$ when $\left(p_{i}-r_{i}\right)-Z_{1 \alpha / 2 k} \times \sqrt{p_{i}\left(1-p_{i}\right) / n_{i}+r_{i}\left(1-r_{i}\right) / m_{i}}<0$ and $\left(p_{i}-r_{i}\right)+Z_{1 \alpha / 2 k} \times \sqrt{p_{i}\left(1-p_{i}\right) / n_{i}+r_{i}\left(1-r_{i}\right) / m_{i}}>0$.

Data for non-numeric ecological factors (VT, TO, DT, SL and SA; see Table I) were examined with chi-square tests. Data for the remaining numeric ecological variables were initially analyzed with one-sample Kolmogorov-Smirnov tests to determine if they were normally distributed. The normally distributed data were analyzed with independent-samples t-tests, while the non-normally distributed data were analyzed with KruskalWallis $\mathrm{H}$ tests.

\section{RESULTS}

A total of 602 plots used by C. e. alxaicus (observed plots) were recorded and compared among the four vegetation zones
(Fig. 3). Across the whole study period, 209 used plots in the coniferous forest mountain zone were measured, and this type was the most common vegetation type, followed by open mountain forest and steppe zone of 169 plots, mountain steppe zone of 108 plots and alpine shrub and meadow zone of 106 plots (Fig. 3).

Across the entire study area in spring, we sampled 181 plots used by deer (Fig. 3) and 181 comparison plots (Appendix 1). Deer selected habitats characterized by gentle $\left(<10^{\circ}\right)$, undulating, sunny slopes in spring. Deer preferred habitats with 4-6 $\mathrm{m}$ high trees, near dense shrubs $\left(>10\right.$ trees $\left./ 100 \mathrm{~m}^{2}\right)$ taller than $1.3 \mathrm{~m}$, with high herb coverage of more than 50\%, good hiding conditions (hiding cover lower than 50\%) (Fig. 4), and distant from bare rock. However, no significant preference was shown during spring with respect to dominant tree species $\left(\chi^{2}\right.$ $=9.65, \mathrm{df}=10, \mathrm{p}>0.05)$, distance to the nearest tree $\left(\chi^{2}=4.02\right.$, $\mathrm{df}=2, \mathrm{p}>0.05)$, altitude $\left(\chi^{2}=0.59, \mathrm{df}=3, \mathrm{p}>0.05\right)$, distance to water resource $\left(\chi^{2}=0.59, \mathrm{df}=2, \mathrm{p}>0.05\right)$, or distance to human disturbance $\left(\chi^{2}=0.00, \mathrm{df}=2, \mathrm{p}>0.05\right)$ (Appendix 1 ).

In summer, 146 plots were used by deer (Fig. 3) and 167 comparison plots (Appendix 1) were surveyed. Deer preferred habitats with gentle, undulating slopes $\left(<20^{\circ}\right)$ on the south side of the MCF zone above 2,000 $\mathrm{m}$ and the ABM zone above 3,000 $\mathrm{m}$, respectively, during summer. Habitats used in summer were on lower slopes near dense stands of trees $\left(>4\right.$ tree/100 $\left.\mathrm{m}^{2}\right)$ with mixed tree species of 4-6 $\mathrm{m}$ height, near dense shrub stands (> 10 tree/100 $\mathrm{m}^{2}$ ) taller than $1.3 \mathrm{~m}$, with high herb coverage (> 80\%), good hiding condition (hiding coverage lower than $50 \%$ ) (Fig. 4) and far from bare rock (> $50 \mathrm{~m}$ ). Distance to human disturbance did not affect habitat use by deer in summer (Appendix 1).

A total of 144 plots used by deer (Fig. 3) and 138 comparison plots (Appendix 1) were surveyed in autumn. Autumn habitat use was similar to that during summer: C. e. alxaicus preferred habitats with gentle $\left(<10^{\circ}\right)$, undulating and partially shaded slopes in the ABM zone, at elevations above 3,000 $\mathrm{m}$ in autumn. They also preferred habitats with more gentle slopes, high tree density $\left(>4\right.$ trees $\left./ 100 \mathrm{~m}^{2}\right)$, mixed tree species of 4-6 $\mathrm{m}$ height, dense shrubs ( $>10$ trees $/ 100 \mathrm{~m}^{2}$ ), high herb coverage (> 80\%) good hiding condition (hiding coverage lower than $50 \%$ ) (Fig. 4), and distant from bare rock (> $100 \mathrm{~m}$ ). There was no significant difference between the used plots and comparison plots in autumn with respect to distance to the nearest tree $\left(\chi^{2}=0.36, d f=2, p>0.05\right)$, shrub height $\left(\chi^{2}=4.00, d f=2\right.$, $\mathrm{p}>0.05)$, distance to water resource $\left(\chi^{2}=2.95, \mathrm{df}=2, \mathrm{p}>0.05\right)$, or distance to human disturbance $\left(\chi^{2}=5.41, \mathrm{df}=2, \mathrm{p}>0.05\right)$ (Appendix 1).

131 plots used by C. e. alxaicus (Fig. 3) and 131 comparison plots (Appendix 1) were surveyed in winter. Deer preferred winter habitats with gentle $\left(<10^{\circ}\right)$, undulating, sunny slopes, lower slopes with high herb coverage ( $>50 \%$ ), and average hiding condition (hiding coverage lower than 75\%) (Fig. 4). However, deer maintained a distance of more than $1.5 \mathrm{~m}$ from shrubs 

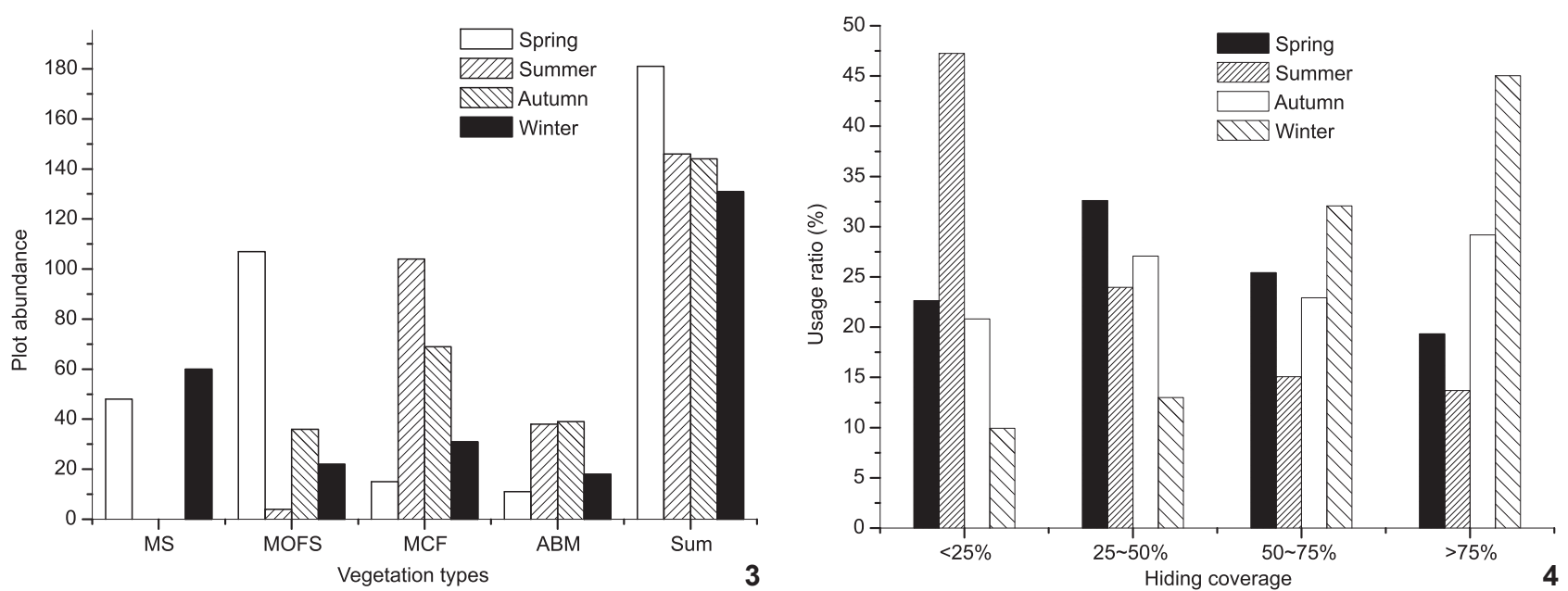

Figures 3-4. (3) Abundance and proportion of plots used by Cervus elaphus alxaicus in different vegetation type zones among four seasons, in the Helan Mountain region, China. (MS) Mountain steppe zone, (MOFS) Mountain open forest and steppe zone, (MCF) Mountain coniferous forest zone, (ABM) Alpine bush and meadow zone. (4) Seasonal changes in the usage ratio of hiding coverage on C. e. alxaicus in the Helan Mountain region, China.

and 50-100 m from bare rock. Deer showed no significant preference with respect to vegetation type $\left(\chi^{2}=0.90, \mathrm{df}=3\right.$, $\mathrm{p}>0.05)$, shrub height $\left(\chi^{2}=2.40, \mathrm{df}=2, \mathrm{p}>0.05\right)$, altitude $\left(\chi^{2}=1.59, \mathrm{df}=3, \mathrm{p}>0.05\right)$, distance to water source $\left(\chi^{2}=0.14\right.$, $\mathrm{df}=2, \mathrm{p}>0.05)$, or distance to human disturbance $\left(\chi^{2}=2.13\right.$, $\mathrm{df}=2, \mathrm{p}>0.05)$ (Appendix 1).

There were statistically significant differences in the use of five non-numeric ecological factors by season. Cervus elaphus alxaicus selected habitats by season based on vegetation type $\left(\chi^{2}=58.611, \mathrm{df}=3, \mathrm{p}<0.001\right)$, topography $\left(\chi^{2}=969.841, \mathrm{df}=3\right.$, $\mathrm{p}<0.001)$, dominant tree species $\left(\chi^{2}=820.947, \mathrm{df}=10\right.$, $\mathrm{p}<0.001)$, slope aspect $\left(\chi^{2}=74.355, \mathrm{df}=2, \mathrm{p}<0.001\right)$ and slope location $\left(\chi^{2}=143.096, \mathrm{df}=2, \mathrm{p}<0.001\right)$. There were also statistically significant differences in the use of 13 numeric ecological factors by season (Table II).

\section{DISCUSSION}

Cervus elaphus alxaicus in the Helan Mountains displayed a pattern of seasonal elevational migration similar to that of other red deer subspecies in mountainous areas (Albon \& Langvatn 1992, Jarnemo 2008, Pépin et al. 2008). However, we observed differences between the habitat selection of $C$. e . alxaicus and that of other subspecies. HutTo (1985) described the mechanisms determining habitat selection as: geographic restrictions, genetic evolution, influence of experience, and settlement decisions following exploration.

Vegetation type determines the composition and distribution of deer forage, and is determined by soil type, climate, sunlight, topography, landform and many microhabitat factors. The heterogeneous distribution of biotic and abiotic fac- tors in environments leads to spatial heterogeneity in vegetation types. Physiological and ecological requirements of deer are met to varying degrees by different vegetation types. Thus the geographic and seasonal variation in vegetation types affect red deer habitat selection. In the Helan Mountains, C. e. alxaicus range annually from the mountain steppe zone below $1,600 \mathrm{~m}$ to alpine shrub and meadow zone above 3,000 $\mathrm{m}$ (Liu 2009). Deer preferred habitats in the montane coniferous forest zone (>2,000 masl) and alpine shrub and meadow zone (> 3,000 masl), in summer, and those in the alpine shrub and meadow zone $(>3,000 \mathrm{~m})$ in autumn. Deer showed no preference for any vegetation type in spring or winter (Appendix 1), using habitats in proportion to their availability during those seasons. Igota et al. (2004) reported that deer rarely change their summer home ranges for breeding and nursing of offspring. We predicted that some C. e. alxaicus might migrate down from the alpine shrub and meadow zone during winter and spring, while some might stay at high altitude. Further study with GPS collars on C. e. alxaicus has been conducted to test the prediction.

Cur et al. (2007) and Chang et al. (2010) reported that $U$. glaucescens, Populus davidiana Dode, P. monglica, Potentilla spp., Graminoids (Stipa spp., Poa spp.), Caragana spp. were important in the winter diet of C. e. alxaicus. In summer, C. e. alxaicus ate 18 plant species of 11 families, which were mostly Salix microstachya var. bordensis (Nakai) C.F. Fang, P. davidiana, U. glaucescens and Agropyron cristatum (L.) Gaertn. which were mainly distributed in the mountainous open forest and steppe zone, ranging from $1,600 \mathrm{~m}$ to $2,000 \mathrm{~m}$ altitude, and C.e. alxaicus of migratory group migrated down from alpine shrub and meadow zone during winter and spring (Table II) as the 
amount of food resources declined. Food availability is clearly critical for the nutrition of ungulates, especially for fawns and females (Pettorelli et al. 2005). Adaptation to varying feeding conditions throughout seasons or years was also confirmed by Groot \& Hazebroek (1995).

Habitat selection by deer is determined by the presence of both food and hiding cover (BORKOWSKI \& UKALSKA 2008). The role of hiding cover in habitat use may be especially important in winter, when cervids reduce their food intake and survive, to a large extent, using their fat reserves (PUTMAn 1988). Peer et al. (1982) studied the role of cover in habitat selection. Two cover types were recognized: thermal cover, in which a forest overstory protects against weather and sun, and hiding (security) cover used to escape and avoid predators and humans. C. e. alxaicus in the Helan Mountains preferred habitats near cover to open habitats in winter, but the reverse was found in summer and autumn (Fig. 4). Habitats dominated by $U$. glaucescens and Juglans regia Linnaeus were frequently used in winter (Appendix 1). C. e. alxaicus are likely to be under low predation risk except from poaching in the Helan Mountains. Therefore, selection of habitat by deer mainly reflects their food requirements and need for protection against severe weather. The habitat selection process presumably results from demands to maximize their energy efficiency while minimizing their movements when searching for food, water and cover (QIAO et al. 2006). It differed from other subspecies of red deer, such as Cervus elaphus xanthopygus MilneEdwards, 1867 in northeast China and Cervus elaphus nelsoni (Bailey, 1935) in the Rocky Mountains, which preferred coniferous forest and sapling trees and shrubs, feeding on shrub and epicormics in winter (UNSWORTH et al. 1998). C. e. alxaicus preferred montane coniferous forest and alpine shrub and meadow zones in summer and autumn, but preferred mountain steppe and mountain open forest and steppe zones in winter and spring, similar to Cervus elaphus scoticus Lönnberg, 1906 (Welch et al. 1990).

The special alpine topography and arid climate in the Helan Mountain region were the two important factors explaining the habitat selection of C. e. alxaicus. Given that precipitation is low in the Helan Mountain region, especially in winter, and the snow coverage is also very low (GeNG \& YANG 1990), the snow depth and coverage are not important factors initiating the habitat selection and movement of C. e. alxaicus. The local population of blue sheep is widespread and numbers more than 10,000 (Liv 2009, Liv et al. 2007b). Blue sheep inhabit the mountain open forest and steppe zone, and probably compete with deer for forage, especially in winter and early spring, when food is scarce (Liv et al. 2007a). We recorded migration of C.e. alxaicus during winter and early spring to the mountain open forest and steppe zone from higher altitude areas (Appendix 1). A reasonable assumption is that blue sheep density, to a certain degree, has a negative influence on C. e. alxaicus density, which might also explain deer movements to higher el- evations in summer. Further study on the niche overlap between blue sheep and C. e. alxaicus is underway. Ager et al. (2003) reported sympatric populations of Rocky Mountain elk (C. e. nelsoni) and mule deer, Odocoileus hemionus (Rafinesque, 1817), in northeastern Oregon, where elk exhibited strong daily and seasonal patterns of movements and habitat use under competition from mule deer.

Topography and slope gradient were important factors affecting habitat selection by C. e. alxaicus. Generally, deer preferred gentle $\left(<10^{\circ}\right)$, undulating slopes (Appendix 1), but this varied seasonally according to food availability and temperature (Fig. 5). Deer selection of lower slopes was also caused by the predominantly steep topography of the Helan range, which includes only a small proportion of the total area as gentle slopes (Di 1986). C. e. alxaicus preferred sunny slopes with direct solar radiation, especially during the cold winter and spring (Fig. 5).

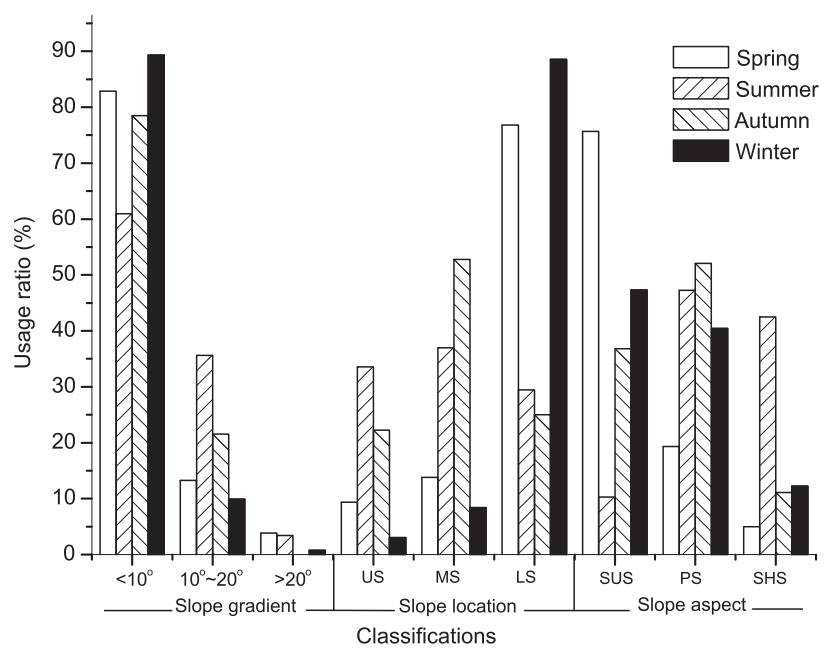

Figure 5. Seasonal changes in the effect of slope characteristics on Cervus elaphus alxaicus. (US) Upper Slope, (MS) Middle Slope, (LS) Lower Slope, (SUS) Sunny Slope, (PS) Partial shade slope, (SHS) Shady slope.

Pressure from predators and human disturbance are often considered to be important factors that influence ungulate behavior and habitat selection (BONENFANT et al. 2004, BORKOWSKI 2004). However, historically, the main predators of C.e. alxaicus, the snow leopard, Uncia uncia (Schreber,1775); the gray wolf, Canis lupus Linnaeus, 1758; and lynx, Lynx lynx (Linnaeus, 1758), became extinct during the 1980s in the Helan mountain region (WANG \& SCHALler 1996). Numerous studies have demonstrated that deer behavior and habitat use are mostly influenced by humans (BORKOWSKI \& UKALSKA 2008), including hunting, other human activities (Licoppe 2006), travel routes 
and road traffic (Yost \& Wright 2001). Jiang et al. (2007) reported that C. e. xanthopygus in northeastern China showed some behavioral plasticity in response to human influences, and the effect of habitat loss or fragmentation caused by human activities are expected to be great (JAEGER et al. 2005). However, in the Helan Mountain region, we found that the deer neither preferred nor avoided human disturbance $(\mathrm{p}>0.05)$ (Appendix 1), and they profited from the programs of ForestGrass Conservation Project and Shelterbelt Forestry Project and Returning Husbandry to Forestry (Grass) launched in 1996 (ZнаO et al. 2000) and 1999 (Zнао et al. 2004), respectively. Wild animal hunting and livestock grazing have been forbidden in most of the Helan Mountain region and habitats are generally wellpreserved. Therefore, C. e. alxaicus has not suffered much human disturbance, apart from regular ranger, activities whose impact is probably negligible. However, in our data, there was a significant amount of seasonal variation in deer avoidance of human disturbance in the Helan Mountains (Table II). The migration of C. e. alxaicus individuals to lower altitudes for foraging in winter and spring has brought deer closer to areas that are impacted by humans. Deer preferred habitats far from human disturbance at higher elevations during summer and autumn. During our survey, human-related C. e. alxaicus fatalities were low compared to those of other studies (Licoppe 2006, Pépin et al. 2008); therefore, limited persecution and food availability may have facilitated and encouraged C.e. alxaicus individuals to use human-impacted areas in winter and spring.

Many studies on ungulate seasonal movement and habitat selection are based on data provided by GPS-collars or radio-collars, which are very precise. However, because of the difficulties involved in capturing C. e. alxaicus and the rugged topographic conditions in the Helan Mountains, we conducted our surveys by comparing use versus availability of habitats to quantify the seasonal habitat selection of C. e. alxaicus. This study was based on several years of observation and one year of data collection, but the biodiversity and natural conditions in the Helan Mountains have remained stable for years due to its continental climate. Understanding habitat selection by the red deer and its strategies of seasonal movement can be used for decision making on appropriate management and conservation measures (GUISAN \& Thuiller 2005) for C. e. alxaicus and its habitat.

\section{ACKNOWLEDGMENTS}

Our project was financially supported by the National Nature Science Foundation of China (\#30970371), Program for New Century Excellent Talents in University (\#NCET-08-0753), the Fundamental Research Funds for the Central Universities (\#DL09CA03, \#DL13EA01-01), and the Optional Project of Ningxia Hui Autonomous Region (2011-017). We are grateful for the support of Ningxia and Inner Mongolia the Helan Mountain National Nature Reserve. We would like to thank Wang Zhaoding for his great efforts and expertise in conducting field research. We also thank two anonymous reviewers and Tom Dahmer for valuable review of this manuscript.

\section{LITERATURE CITED}

Ager, A.A.; B.K. Johnson; J.W. Kern \& J.G. Kie. 2003. Daily and seasonal movements and habitat use by female rocky mountain elk and mule deer. Journal of Mammalogy 84 (3): 1076-1088.

Albon, S.D. \& R. Langvatn. 1992. Plant phenology and the benefits of migration in a temperate ungulate. Oikos 65: 502-513.

Table II. Characteristics of 13 ecological factors in the habitats used by Cervus elaphus alxaicus during the year in the Helan Mountain region, China. Significant P-values: * $p \leqslant 0.001$.

\begin{tabular}{|c|c|c|c|c|c|}
\hline Ecological factors & Spring (mean \pm SE) & Summer $($ mean $\pm S E)$ & Autumn (mean $\pm \mathrm{SE}$ ) & Winter $($ mean \pm SE) & $\begin{array}{c}\text { Kruskal-Wallis } \\
\mathrm{H} \text { Test } \chi^{2}\end{array}$ \\
\hline TD (individuals/100 $\mathrm{m}^{2}$ ) & $2.06 \pm 5.065$ & $8.89 \pm 10.258$ & $3.13 \pm 5.634$ & $2.90 \pm 4.642$ & $58.051^{*}$ \\
\hline TH $(m)$ & $1.91 \pm 2.050$ & $3.09 \pm 2.561$ & $1.66 \pm 2.423$ & $1.90 \pm 1.879$ & $3.319^{\star}$ \\
\hline DtT (m) & $13.28 \pm 11.243$ & $9.83 \pm 11.437$ & $17.01 \pm 10.845$ & $12.81 \pm 11.129$ & $60.433^{*}$ \\
\hline SD (individuals $/ 100 \mathrm{~m}^{2}$ ) & $12.08 \pm 10.954$ & $19.20 \pm 13.947$ & $12.29 \pm 11.127$ & $6.70 \pm 10.808$ & $76.191^{*}$ \\
\hline $\mathrm{SH}(\mathrm{m})$ & $0.95 \pm 1.012$ & $0.90 \pm 0.567$ & $0.64 \pm 0.611$ & $0.64 \pm 3.499$ & $71.366^{\star}$ \\
\hline DtS (m) & $3.24 \pm 3.782$ & $1.51 \pm 2.143$ & $3.29 \pm 3.795$ & $6.30 \pm 4.252$ & $78.617^{*}$ \\
\hline HC (\%) & $67.84 \pm 23.194$ & $82.40 \pm 23.873$ & $88.56 \pm 17.755$ & $66.98 \pm 24.664$ & $126.156^{*}$ \\
\hline SG $\left(^{\circ}\right)$ & $5.55 \pm 6.151$ & $10.21 \pm 10.977$ & $6.40 \pm 3.350$ & $4.61 \pm 6.081$ & $75.136^{*}$ \\
\hline $\mathrm{AL}(\mathrm{m})$ & $1,903.62 \pm 427.717$ & $2,512.13 \pm 375.169$ & $2,512.46 \pm 493.990$ & $1,890.61 \pm 570.243$ & $203.163^{*}$ \\
\hline $\mathrm{DtW}(\mathrm{m})$ & $1,060.92 \pm 1351.187$ & $1,176.24 \pm 863.845$ & $1,510.63 \pm 1221.745$ & $1,327.50 \pm 1431.247$ & $26.920^{*}$ \\
\hline $\mathrm{DtH}(\mathrm{m})$ & $2,933.31 \pm 1907.579$ & $5,380.26 \pm 3124.869$ & $7,255.49 \pm 3343.345$ & $3,134.27 \pm 1913.725$ & $158.822^{*}$ \\
\hline $\mathrm{DtR}(\mathrm{m})$ & $120.04 \pm 185.693$ & $186.05 \pm 168.370$ & $247.47 \pm 222.321$ & $75.61 \pm 217.001$ & $178.969^{*}$ \\
\hline $\mathrm{HiC}(\%)$ & $47.36 \pm 27.710$ & $35.80 \pm 28.239$ & $52.68 \pm 27.888$ & $67.25 \pm 24.434$ & $86.234^{*}$ \\
\hline
\end{tabular}

ZOOLOGIA 30 (1): 24-34, February, 2013 
Bonenfant, C.; E.L. Leif; A. Mysterud; R. Langvatn; N.C. Stenseth; J.M. Gaillard \& F. Klein. 2004. Multiple causes of sexual segregation in European red deer: enlightenments from varying breeding phenology at high and low latitude. Proceedings of the Royal Society B Biological Sciences 271: 883-892.

BоRкоWSкI, J. \& J. UкALSKa. 2008. Winter habitat use by red and roe deer in pine-dominated forest. Forest Ecology and Management 255: 468-475.

Borkowski, J. 2004. Distribution and habitat use by red and roe deer following a large forest fire in South-western Poland. Forest Ecology and Management 201: 287-293.

Brinkman, T.J.; C.S. Deperno; J.A. Jenks; B.S. Haroldson \& R.G. Osborn. 2005. Movement of female white-tailed deer: effects of climate and intensive row-crop agriculture. The Journal of Wildlife Management 69 (3): 1099-1111.

Byers, C.R.; K. Steinhorst \& P.R. Krausman. 1984. Clarification of a technique for analysis of utilization-availability data. The Journal of Wildlife Management 48: 1050-1053.

Chang, H. \& Q.Z. XIAO. 1988. Selection of winter habitat of Red deer in Dailing region. Acta Theriologica Sinica 8 (2): 81-88.

Chang, Y.; M.M. Zhang; Z.S. Liu; T.H. Hu \& Z.G. LI. 2010. Summer Dies of Sympatric Blue Sheep (Pseudois nayaur) and Red Deer (Cervus elaphus alxaicus) in the Helan Mountains, China. Acta Ecologica Sinica 30 (6): 1486-1493.

CuI, D.Y.; Z.S. LiU; X.M. WANG; H. Zhai; T.H. Hu \& Z.G. Li. 2007. Winter food-habits of red deer in the Helan Mountains, China. Zoological Research 28 (4): 383-388.

DI, W.Z. 1986. Plantae vasculares the Helan Mountain. Xi'an, Northwestern University Press.

Fryxell, J.M. \& A.R.E. Sinclair. 1988. Causes and consequences of migration by large herbivores. Trends in Ecology \& Evolution 3 (9): 237-241.

GenG, K. \& Z.R. YANG. 1990. Climatic characteristics and climatic landforms in Helan Mountain. Yantai Teacher's College Journal (Natural Science Edition) 6 (2): 49-56.

Groot, B. \& E. Наzевroeк. 1995. Ingestion and diet composition of red deer (Cervus elaphus L.) in the Netherlands from 1954 till 1992. Mammalia 59: 187-195.

Grovenburg, T.W.; J.A. Jenks; R.W. Klaver; C.C. Swanson; C.N. JACQUes \& D. Todry. 2009. Seasonal movements and home ranges of white-tailed deer in north-central South Dakota. Canadian Journal of Zoology 87 (10): 876-885.

Guisan, A. \& W. Thuiller. 2005. Predicting species distribution: offering more than simple habitat models. You have full text access to this content. Ecology Letters 8 (9): 993-1009.

Hutto, R.L. 1985. Habitat selection in birds. New York, Academic Press, 558p.

Igota, H.; M. Sakuragi; H. Uno; K. Kaji; M. Kaneko; R. Akamatsu \& K. MaEKAWA. 2004. Seasonal migration patterns of female sika deer in eastern Hokkaido, Japan. Ecological Research 19 (2): 169-178.

Jaeger, J.A.G; J. Bowman; J. Brennan; L. Fahrig; D. Bert; J. Bouchard; N. Charbonneau; K. Frank; B. Gruber \& K.T. Von Toschanowitz.
2005. Predicting when animal populations are at risk from roads: an interactive model of road avoidance behavior. Ecological Modelling 185 (2-4): 329-348.

JARNemo, A. 2008. Seasonal migration of male red deer (Cervus elaphus) in southern Sweden and consequences for management. European Journal of Wildlife Research 54 (2): 327-333.

JEPPESEN, J.L. 1987. Impact of human disturbance on home range, movements and activity of red deer (Cervus elaphus) in a Danish environment. Danish Review of Game Biology 13 (2): 35-38.

JIANG, G.S.; J.Z. MA \& M.H. ZHANG. 2007. Effects of human disturbance on movement, foraging and bed selection in red deer Cervus elaphus xanthopygus from the Wandashan Mountains, northeastern China. Acta Theriologica 52 (4): 435-446.

Jiang, Y.; M. Kang; S. Liu; L.S. Tian \& M.D. Lei. 2000. A study on the vegetation in the east side of Helan Mountain. Plant Ecology 149 (2): 119-130.

Kunkel, K. \& D.H. Pletscher. 2001. Winter hunting patterns of wolves in and Near Glacier National Park, Montana. The Journal of Wildlife Management 65 (3): 520-530.

Licoppe, A.M. 2006. The diurnal habitat used by red deer (Cervus elaphus L.) in the Haute Ardenne. European Journal of Wildlife Research 52 (3): 164-170.

LiU, Z.S. 2009. Notes of vertebrates in the Helan Mountain. Yinchuan, Ningxia People's Publishing House.

LiU, Z.S.; X.M. WANG; Z.G. Li; D.Y. CuI \& X.Q. Li. 2007a. Feeding habitats of blue sheep (Pseudois nayaur) during winter and spring in the Helan Mountains, China. Frontiers of Biology in China 2 (1): 100-107.

LiU, Z.S.; X.M. WANG; Z.G. LI; H. Zhai \& T.H. Hu. 2007b. Distribution and abundance of blue sheep in the Helan Mountains, China. Chinese Journal of Zoology 42 (3): 1-8.

LiU, Z.S.; J.P. Wu \& L.W. Teng. 2002. Time budget and behavior pattern of semi free Cervus nippon in spring. Chinese Journal of Ecology 21 (6): 29-32.

Lovari, S.; J. Herrero; J. Conroy; T. Maran; G. Giannatos; M. Stubbe; S. Aulagnier; T. Jdeidi; M. Masseti; I. Nader; K. De Smet \& F. CuzIN. 2008. Cervus elaphus. In: IUCN 2010 (Ed). IUCN Red List of Threatened Species. Version 2010.4. Available online at: http://www.iucnredlist.org/apps/redlist/details/ 41785/0 [Accessed: 12/X/2011].

Manly, B.F.J.; L.L. Mcdonald; D.L. Thomas; T.L. Mcdonald \& W.P. ERICKSON. 2002. Resource selection by animals: statistical design and analysis for field studies. London, Chapman \& Hall.

Marcum, C.L. \& D.O. Loftsgaarden. 1980. A nonmapping technique for studying habitat preferences. The Journal of Wildlife Management 44 (4): 963-968.

Moen, A.N. 1976. Energy conservation by white-tailed deer in the winter. Ecology 57: 192-198.

Morrison, M.L.; B.G. Marcot \& R.W. Mannan. 1998. Wildlifehabitat relationships: concepts and applications. Madison, The University of Wisconsin Press. 
Neu, C.W.; C.R. Byers \& J.M. Peek. 1974. A technique for analysis of utilization-availability data. The Journal of Wildlife Management 38 (3): 541-545.

Peek, J.M.; M.D. Scott; L.J. Nelson \& D.J. Pierce. 1982. Role of cover in habitat management for big game in northwestern United States. Transactions of North American Wildlife and Natural Resources Conference 47: 363-373.

Pépin, D.; C. Adrados; G. Janeau; J. Joachim \& C. Mann. 2008. Individual variation in migratory and exploratory movements and habitat use by adult red deer (Cervus elaphus) in a mountainous temperate forest. Ecological Research 23 (2): 1005-1013.

Pettorelli, N.; A. Mysterud; N.G. Yoccoz; R. Langvatn \& N.C. Stenseth. 2005. Importance of climatological downscaling and plant phenology for red deer in heterogeneous landscapes. Proceedings of the Royal Society Biological Sciences 272: 2357-2364.

Putman, R. 1988. The Natural History of Deer. London, Christopher Helm.

QIAO, J.F.; W.K. YANG \& X.Y. GaO. 2006. Natural diet and food habitat use of the Tarim red deer, Cervus elaphus yarkandensis. Chinese Science Bulletin 51 (Supp. I): 147-152.

Schmitz, O.J. 1991. Thermal constrains and optimization of winter feeding and habitat choice in white-tailed deer. Ecography 14: 104-111.

Takhtajan, A. 1986. Floristic regions of the world. Berkeley, University of California Press, 62p.

Unsworth, J.W.; L. KuCK; E.O. Garton \& B.R. Butterfield. 1998. Elk habitat selection on Clearwater national forest, Idaho. The Journal of Wildlife Management 62 (4): 1255-1263.

Vaughan, T.A.; J.M. Ryan \& N.J. CZaplewski. 2000. Mammalogy. Orlando, Saunders College Publishing, $4^{\text {th }}$ ed.

WANG, S. 1998. China red data book of endangered animals: mammals. Beijing, Science Press.
WANG, X.M.; M. LI; S.Y. TANG; Z.X. LiU; Y.G. Li \& H.L. Sheng. 1999. The Study of resource and conservation of artiodactyls in the Helan Mountain. Chinese Journal of Zoology 34 (5): 26-29.

WANG, X.M. \& G.B. SCHALler. 1996. Status of large mammals in Inner Mongolia, China. Journal of East China Normal University 6 (Special Issue): 94-104.

Welch, D.; B.W. Staines; D.C. Catt \& D. Scott. 1990. Habitat usage by red (Cervus elaphus) and roe deer (Capreolus capreolus) in a Scottish Sitka Apruce plantation. Journal of Zoology 221 (3): 453-476.

White, C.G. \& R.A. Garrott. 1990. Analysis of Wildlife RadioTracking Data. San Diego, Academic Press.

Yost, A.C. \& R.G. Wright. 2001. Moose, Caribou, and Grizzly Bear distribution in relation to road traffic in Denali National Park, Alaska. Arctic 54 (1): 41-48.

Zhang, X.L.; Z.G. Li; Z. Li; Y.X. Ma; T.S. Zhang \& H. Zhai. 2006. Studies on population quantity and dynamics of red deer in spring for Helanshan Mountain of Ningxia. Journal of Ningxia University (Natural Science Edition) 27 (3): 263-265.

ZhanG, X.L.; Z.G. LI; H.J. LÜ \& H.L. Guo. 1999. Studies on ecological habits and population dynamics of Ningxia red deer. Ningxia Journal of Agriculture and Forestry Science and Technology (Supp. I): 22-27.

ZhaO, C.L.; Z.G. LI; H.J. LÜ; T. LI; T.H. Hu; H. Zhai; H.L. WANG; Y.X. LI; Z.C. WanG; Z.L. ChanG; R.F. JiAO; H.Y. SHI \& H.P. XU. 2000. Vegetation cover degree monitoring in the Helanshan Mountain project area of Sino-Germany cooperation Ningxia shelter-forest project. Ningxia Journal of Agriculture and Forestry Science and Technology (Supp. I): 6-14.

Zнао, Y.S.; P. Sun; X.Q. Zhou \& D.J. Cuı. 2004. The role of closing hills for reforestation on eco-environment in the Helanshan Mountains. Inner Mongolia Forestry Investigation and Design 27 (4): 7-9. 
Appendix 1. The proportion of 18 ecological factors in used (Obs) plots by Cervus elaphus alxaicus and comparison (Exp) plots during different seasons in the Helan Mountain region, China. Selection was determined according to the method of BYers et al. (1984). Factors: (AL) Altitude, (VT) Vegetation types, (TO) Topography, (DT) Dominant tree, (TD) Tree density, (TH) Tree height, (DtT) Distance to the nearest tree, (SD) Shrub density, (SH) Shrub height, (DtS) Distance to the nearest shrub, (HC) Herb coverage, (SG) Slope gradient, (SL) Slope location, (SA) Slope aspect, (DtW) Distance to water resource, (DtH) Distance to human disturbance, (DtR) Distance to bare rock, (HiC) Hiding cover.

\begin{tabular}{|c|c|c|c|c|c|c|c|c|c|c|c|c|c|}
\hline \multirow{2}{*}{ Factors } & \multirow{2}{*}{ Item } & \multicolumn{3}{|c|}{ Spring } & \multicolumn{3}{|c|}{ Summer } & \multicolumn{3}{|c|}{ Autumn } & \multicolumn{3}{|c|}{ Winter } \\
\hline & & Obs & Exp & $\chi^{2}($ Sig) & Obs & Exp & $\chi^{2}($ Sig) & Obs & Exp & $\chi^{2}($ Sig) & Obs & Exp & $\chi^{2}($ Sig) \\
\hline \multirow[t]{4}{*}{ VT } & MS & $48(=)$ & 45 & $p<0.05$ & $0(-)$ & 45 & $p<0.01$ & $0(-)$ & 26 & $p<0.01$ & $60(=)$ & 56 & $p>0.05$ \\
\hline & MOFS & 107(=) & 108 & & $4(-)$ & 28 & & $36(=)$ & 47 & & $22(=)$ & 26 & \\
\hline & MCF & $15(=)$ & 17 & & $104(+)$ & 71 & & $69(=)$ & 48 & & $31(=)$ & 31 & \\
\hline & $\mathrm{ABM}$ & $11(=)$ & 11 & & $38(+)$ & 23 & & $39(+)$ & 17 & & $18(=)$ & 18 & \\
\hline \multirow[t]{5}{*}{ TO } & Smooth undulating slope & $156(+)$ & 12 & $p<0.01$ & $82(+)$ & 8 & $p<0.01$ & $120(+)$ & 7 & $p<0.01$ & $112(+)$ & 44 & $\mathrm{p}<0.01$ \\
\hline & Moderately broken slope & $19(-)$ & 42 & & $64(+)$ & 16 & & $24(+)$ & 5 & & $18(-)$ & 43 & \\
\hline & Distinctly broken slope & $6(-)$ & 70 & & $0(-)$ & 97 & & $0(-)$ & 83 & & $0(-)$ & 36 & \\
\hline & Scree/landslide & $0(-)$ & 26 & & $0(-)$ & 10 & & $0(-)$ & 21 & & $0(=)$ & 5 & \\
\hline & Cliff & $0(-)$ & 31 & & $0(-)$ & 36 & & $0(-)$ & 22 & & $1(=)$ & 3 & \\
\hline \multirow[t]{11}{*}{ DT } & Ulmus glaucescens & $54(=)$ & 54 & $p>0.05$ & $0(-)$ & 23 & $\mathrm{p}<0.01$ & $9(=)$ & 17 & $p<0.01$ & $47(=)$ & 54 & $\mathrm{p}<0.01$ \\
\hline & Ziziphus jujuba var.spinosa(Bunge)Hu & $2(=)$ & 0 & & $0(=)$ & 0 & & $0(=)$ & 1 & & $5(=)$ & 0 & \\
\hline & Salix babylonica $\odot$ & $3(=)$ & 0 & & $0(=)$ & 1 & & $0(=)$ & 1 & & $2(=)$ & 0 & \\
\hline & Juniperus rigida & $11(=)$ & 16 & & $20(=)$ & 19 & & $11(=)$ & 12 & & $8(=)$ & 8 & \\
\hline & Pinus tabulaeformis & $1(=)$ & 3 & & $1(=)$ & 4 & & $3(=)$ & 1 & & $2(=)$ & 9 & \\
\hline & Picea crassifolia & $4(=)$ & 8 & & $32(=)$ & 27 & & $18(=)$ & 13 & & $0(-)$ & 10 & \\
\hline & Prunus armeniaca & $2(=)$ & 0 & & $0(=)$ & 0 & & $0(=)$ & 0 & & $8(=)$ & 2 & \\
\hline & Juglans regia & $3(=)$ & 0 & & $0(=)$ & 0 & & $0(=)$ & 0 & & $59(=)$ & 48 & \\
\hline & Salix microstachya & $0(=)$ & 0 & & $0(=)$ & 0 & & $0(=)$ & 0 & & $0(=)$ & 0 & \\
\hline & No tree & $86(=)$ & 100 & & $49(-)$ & 91 & & $92(=)$ & 92 & & $0(=)$ & 0 & \\
\hline & Mixture & $15(=)$ & 0 & & $43(+)$ & 2 & & $11(+)$ & 1 & & $0(=)$ & 0 & \\
\hline \multirow[t]{3}{*}{ TD } & $<2$ tree $/ 100 \mathrm{~m}^{2}$ & $114(=)$ & 123 & $\mathrm{p}<0.05$ & $51(-)$ & 107 & $\mathrm{p}<0.01$ & $96(=)$ & 103 & $p<0.01$ & $75(+)$ & 59 & $\mathrm{p}<0.01$ \\
\hline & $2 \sim 4$ tree $/ 100 \mathrm{~m}^{2}$ & $43(=)$ & 46 & & $10(-)$ & 31 & & $10(=)$ & 18 & & $31(=)$ & 42 & \\
\hline & $>4$ tree $/ 100 \mathrm{~m}^{2}$ & $24(=)$ & 12 & & $85(+)$ & 29 & & $38(+)$ & 17 & & $21(=)$ & 30 & \\
\hline \multirow[t]{3}{*}{$\mathrm{TH}$} & $<4 \mathrm{~m}$ & $148(-)$ & 172 & $p<0.01$ & $72(-)$ & 129 & $p<0.01$ & $113(=)$ & 119 & $p>0.05$ & $116(=)$ & 113 & $\mathrm{p}<0.01$ \\
\hline & $4 \sim 6 \mathrm{~m}$ & $30(+)$ & 7 & & $53(+)$ & 31 & & $21(=)$ & 14 & & $13(=)$ & 18 & \\
\hline & $>6 \mathrm{~m}$ & $3(=)$ & 2 & & $21(+)$ & 7 & & $10(=)$ & 5 & & $2(=)$ & 0 & \\
\hline \multirow[t]{3}{*}{ DtT } & $<1 \mathrm{~m}$ & $3(=)$ & 1 & $p>0.05$ & $23(+)$ & 2 & $p<0.01$ & $2(=)$ & 0 & $p>0.05$ & $4(=)$ & 9 & $p<0.05$ \\
\hline & $1 \sim 3 \mathrm{~m}$ & $64(=)$ & 65 & & $69(=)$ & 70 & & $37(=)$ & 39 & & $42(=)$ & 50 & \\
\hline & $>3 \mathrm{~m}$ & $114(=)$ & 115 & & $54(-)$ & 95 & & $105(=)$ & 99 & & $85(=)$ & 72 & \\
\hline \multirow[t]{3}{*}{ SD } & $<5$ tree $/ 100 \mathrm{~m}^{2}$ & $52(-)$ & 81 & $\mathrm{p}<0.01$ & $16(-)$ & 73 & $\mathrm{p}<0.01$ & $50(=)$ & 49 & $p<0.01$ & $84(=)$ & 75 & $\mathrm{p}<0.05$ \\
\hline & $5 \sim 10$ tree/100 $\mathrm{m}^{2}$ & $52(-)$ & 85 & & $37(-)$ & 81 & & $25(=)$ & 62 & & $18(=)$ & 31 & \\
\hline & $>10$ tree $/ 100 \mathrm{~m}^{2}$ & $77(+)$ & 15 & & $93(+)$ & 13 & & $69(+)$ & 27 & & $29(=)$ & 25 & \\
\hline \multirow[t]{3}{*}{ SH } & $<1.3 \mathrm{~m}$ & $134(-)$ & 172 & $p<0.01$ & $111(-)$ & 161 & $p<0.01$ & $120(=)$ & 138 & $p>0.05$ & $123(=)$ & 126 & $p>0.05$ \\
\hline & $1.3 \sim 1.7 \mathrm{~m}$ & $21(+)$ & 8 & & $20(+)$ & 4 & & $11(=)$ & 0 & & $4(=)$ & 3 & \\
\hline & $>1.7 \mathrm{~m}$ & $26(+)$ & 1 & & $15(+)$ & 2 & & $11(=)$ & 0 & & $4(=)$ & 2 & \\
\hline \multirow[t]{3}{*}{ DtS } & $<0.5 \mathrm{~m}$ & $11(+)$ & 5 & $p<0.01$ & $28(+)$ & 5 & $p<0.01$ & $14(=)$ & 5 & $p<0.01$ & $10(=)$ & 7 & $p<0.01$ \\
\hline & $0.5 \sim 1.5 \mathrm{~m}$ & $89(-)$ & 106 & & $75(=)$ & 81 & & $66(=)$ & 71 & & $22(-)$ & 50 & \\
\hline & $>1.5 \mathrm{~m}$ & $81(=)$ & 70 & & $43(-)$ & 81 & & $64(=)$ & 62 & & $99(=)$ & 74 & \\
\hline
\end{tabular}


Appendix 1. Continued.

\begin{tabular}{|c|c|c|c|c|c|c|c|c|c|c|c|c|c|}
\hline \multirow{2}{*}{ Factors } & \multirow{2}{*}{ Item } & \multicolumn{3}{|c|}{ Spring } & \multicolumn{3}{|c|}{ Summer } & \multicolumn{3}{|c|}{ Autumn } & \multicolumn{3}{|c|}{ Winter } \\
\hline & & Obs & $\operatorname{Exp}$ & $\chi^{2}$ (Sig) & Obs & Exp & $\chi^{2}$ (Sig) & Obs & $\operatorname{Exp}$ & $\chi^{2}(\mathrm{Sig})$ & Obs & Exp & $\chi^{2}$ (Sig) \\
\hline \multirow[t]{3}{*}{$\mathrm{HC}$} & $50 \%$ & $48(-)$ & 170 & $\mathrm{p}<0.01$ & $16(-)$ & 142 & $\mathrm{p}<0.01$ & $9(-)$ & 127 & $\mathrm{p}<0.01$ & $33(-)$ & 118 & $p<0.01$ \\
\hline & $50 \sim 80 \%$ & $73(+)$ & 11 & & $26(=)$ & 19 & & $16(=)$ & 10 & & $53(+)$ & 11 & \\
\hline & $>80 \%$ & $60(+)$ & 0 & & $104(+)$ & 6 & & $119(+)$ & 1 & & $45(+)$ & 2 & \\
\hline \multirow[t]{3}{*}{ SG } & $<10^{\circ}$ & $150(+)$ & 16 & $\mathrm{p}<0.01$ & $89(+)$ & 10 & $\mathrm{p}<0.01$ & $113(+)$ & 2 & $\mathrm{p}<0.01$ & $117(+)$ & 27 & $p<0.01$ \\
\hline & $10^{\circ} \sim 20^{\circ}$ & $24(-)$ & 45 & & $52(+)$ & 29 & & $31(=)$ & 33 & & $13(-)$ & 45 & \\
\hline & $>20^{\circ}$ & $7(-)$ & 120 & & $5(-)$ & 128 & & $0(-)$ & 103 & & $1(-)$ & 59 & \\
\hline \multirow[t]{3}{*}{$\mathrm{SL}$} & Upper slope & $17(-)$ & 53 & $p<0.01$ & $49(=)$ & 65 & $\mathrm{p}<0.01$ & $32(=)$ & 45 & $\mathrm{p}<0.01$ & $4(=)$ & 7 & $p<0.01$ \\
\hline & Middle slope & $25(-)$ & 85 & & $54(=)$ & 75 & & $76(=)$ & 77 & & $11(-)$ & 68 & \\
\hline & Lower slope & $139(+)$ & 43 & & $43(+)$ & 27 & & $36(+)$ & 16 & & $116(+)$ & 56 & \\
\hline \multirow[t]{3}{*}{ SA } & Sunny slope & $137(+)$ & 55 & $p<0.01$ & $15(-)$ & 118 & $p<0.01$ & $53(-)$ & 93 & $p<0.01$ & $62(+)$ & 39 & $p<0.01$ \\
\hline & Partial shade slope & $35(-)$ & 76 & & $69(+)$ & 34 & & $75(+)$ & 27 & & $53(=)$ & 49 & \\
\hline & Shady slope & $9(-)$ & 50 & & $62(+)$ & 15 & & $16(=)$ & 18 & & $16(-)$ & 43 & \\
\hline \multirow[t]{4}{*}{$\mathrm{AL}$} & $<1600 \mathrm{~m}$ & $56(=)$ & 52 & $p>0.05$ & $0(-)$ & 44 & $\mathrm{p}<0.01$ & $5(-)$ & 27 & $\mathrm{p}<0.01$ & $52(=)$ & 48 & $p>0.05$ \\
\hline & $1600 \sim 2000 \mathrm{~m}$ & $52(=)$ & 56 & & $4(-)$ & 29 & & $6(-)$ & 27 & & $30(=)$ & 34 & \\
\hline & $2000 \sim 3000 \mathrm{~m}$ & $62(=)$ & 62 & & $119(+)$ & 74 & & $94(+)$ & 67 & & $34(=)$ & 31 & \\
\hline & $>3000 \mathrm{~m}$ & $11(=)$ & 11 & & $23(=)$ & 20 & & $39(+)$ & 17 & & $15(=)$ & 18 & \\
\hline \multirow[t]{3}{*}{ DtW } & $<500 \mathrm{~m}$ & $101(=)$ & 97 & $p>0.05$ & $42(-)$ & 67 & $\mathrm{p}<0.01$ & $44(=)$ & 39 & $p>0.05$ & $54(=)$ & 52 & $p>0.05$ \\
\hline & $500 \sim 1000 \mathrm{~m}$ & $19(=)$ & 22 & & $19(=)$ & 15 & & $21(=)$ & 15 & & $19(=)$ & 19 & \\
\hline & $>1000 \mathrm{~m}$ & $61(=)$ & 62 & & $85(=)$ & 85 & & $79(=)$ & 84 & & $58(=)$ & 60 & \\
\hline \multirow[t]{3}{*}{$\mathrm{DtH}$} & $<500 \mathrm{~m}$ & $34(=)$ & 34 & $p>0.05$ & $2(=)$ & 6 & $p>0.05$ & $0(=)$ & 0 & $p>0.05$ & $8(=)$ & 6 & $p>0.05$ \\
\hline & $500 \sim 1000 \mathrm{~m}$ & $16(=)$ & 16 & & $4(=)$ & 11 & & $0(=)$ & 5 & & $18(=)$ & 14 & \\
\hline & $>1000 \mathrm{~m}$ & $131(=)$ & 131 & & $140(=)$ & 150 & & 144(=) & 133 & & $105(=)$ & 111 & \\
\hline \multirow[t]{3}{*}{ DtR } & $<50 \mathrm{~m}$ & $80(-)$ & 143 & $p<0.01$ & $14(-)$ & 109 & $\mathrm{p}<0.01$ & $7(-)$ & 30 & $\mathrm{p}<0.01$ & $87(-)$ & 109 & $p<0.01$ \\
\hline & $50 \sim 100 \mathrm{~m}$ & $52(+)$ & 18 & & $44(+)$ & 25 & & $48(=)$ & 53 & & $30(+)$ & 13 & \\
\hline & $>100 \mathrm{~m}$ & $49(+)$ & 20 & & $88(+)$ & 33 & & $89(+)$ & 55 & & $14(=)$ & 9 & \\
\hline \multirow[t]{4}{*}{$\mathrm{HiC}$} & $>25 \%$ & $41(+)$ & 2 & $\mathrm{p}<0.01$ & $69(+)$ & 0 & $\mathrm{p}<0.01$ & $30(+)$ & 0 & $\mathrm{p}<0.01$ & $13(+)$ & 0 & $p<0.01$ \\
\hline & $25 \sim 50 \%$ & $59(+)$ & 7 & & $35(+)$ & 13 & & $39(+)$ & 4 & & $17(+)$ & 4 & \\
\hline & $50 \sim 75 \%$ & $46(=)$ & 45 & & $22(=)$ & 21 & & $33(+)$ & 7 & & $42(+)$ & 12 & \\
\hline & $>75 \%$ & $35(-)$ & 127 & & $20(-)$ & 133 & & $42(-)$ & 127 & & $59(-)$ & 115 & \\
\hline
\end{tabular}

The symbols (=), (+) and (-) located beside the observed values signify that those values were found to be (according to Bonferroni Intervals) in equal, greater, or lesser proportion than the respective expected values. (+) indicates that red deer preferred category $\mathrm{i} ;(-)$ indicates that red deer avoided category $\mathrm{i}$; $(-)$ indicates that red deer showed no obvious selection according to category $\mathrm{i}$.

Difference between used and comparison plots is statistically significant at $\mathrm{p}<0.05$ based on a chi-square goodness-of-fit test.

Submitted: 14.XI.2011; Accepted: 06.VIII.2012.

Editorial responsibility: Fernando de C. Passos 